\title{
Opposing Actions of Glucagon and Insulin on Splanchnic D Cell Function
}

\author{
Koichi Kawai and Roger H. Unger, Veterans Administration Medical Center \\ and The University of Texas Health Science Center at Dallas, Department of \\ Internal Medicine, Dallas, Texas 75235
}

A B S TRACT The effect of glucagon at various infusion rates on plasma levels of somatostatin-like immunoreactivity (SLI) was examined in conscious normal and chronic alloxan diabetic dogs. In normal dogs glucagon infused at 6,36 , and $120 \mathrm{ng} / \mathrm{kg}$ per min did not affect the peripheral venous plasma SLI levels. In diabetic dogs, however, peripheral venous plasma SLI levels in inferior vena cava rose significantly from a mean base-line value of $181 \pm 9 \mathrm{pg} / \mathrm{ml}$ to a peak value of $279 \pm 38 \mathrm{pg} / \mathrm{ml}$ during the infusion of $120 \mu \mathrm{g} / \mathrm{kg}$ per min of glucagon, which raised plasma immunoreactive glucagon to $>5,000 \mathrm{pg} / \mathrm{ml}$. This glucagon-mediated increase was completely abolished by coinfusion of 7 $\mathrm{mU} / \mathrm{kg}$ per min of insulin, a rate that maintained the ratio of insulin to glucagon at approximately the baseline value.

In anesthetized normal dogs the concentration of SLI in the venous effluent of the pancreas, the gastric fundus and the antrum increased significantly with each infusion rate of glucagon using including the lowest rate of $4 \mathrm{ng} / \mathrm{kg}$ per min, which raised the plasma level of glucagon to $395 \pm 19 \mathrm{pg} / \mathrm{ml}$. This stimulatory effect on SLI secretion was completely abolished by insulin coinfusion at a rate designed to maintain the insulin to glucagon ratio at approximately the baseline value, but the effect of a high $90-\mathrm{ng} / \mathrm{kg}$ per $\mathrm{min}$ infusion on pancreatic and gastric SLI release was not suppressed by coinfusion of $10 \mathrm{mU} / \mathrm{kg}$ per min insulin.

These results suggest that glucagon stimulates splanchnic D cells unless insulin secretion is proportionally stimulated and suggests that the splanchnic D cell is a common target upon which the two hormones exert opposing actions. The loss of insulin inhibition of glucagon-mediated somatostatin secretion may account for the hypersomatostatinemia of severe diabetes.

Dr. Unger is a Senior Medical Investigator, Dallas Veterans Administration Medical Center.

Received for publication 2 September 1982 and in revised form 17 November 1982.

\section{INTRODUCTION}

Insulin and glucagon reportedly influence somatostatin secretion in vitro (1-5), but their influence on $D$ cell function has not been examined in vivo. The present study was designed to evaluate the effects and interactions of glucagon and insulin on splanchnic somatostatin release in normal and diabetic dogs.

\section{METHODS}

In experiments requiring peripheral venous blood samples only, conscious dogs were studied after an overnight fast. Eight normal mongrel dogs (body wt $22-27 \mathrm{~kg}$ ) and five alloxan diabetic dogs (body wt 20-25 kg) were observed. Diabetes had been induced at least $10 \mathrm{mo}$ earlier by an intravenous injection of alloxan $(75 \mathrm{mg} / \mathrm{kg})$ and the dogs had been treated with neutral protein Hayedorn insulin twice daily until $3 \mathrm{~d}$ before the experiment, at which time all insulin was discontinued. (The presence of severe insulin deficiency was established in each of the dogs in the course of subsequent experiments unrelated to the present work; perfusion of these pancreases with $100 \mathrm{mg} / \mathrm{dl}$ glucose plus $10 \mathrm{mM}$ arginine did not elicit a rise in insulin in any case.) All of the dogs were in apparent good health at the time of their experiment, as evidenced by a normal leukocyte count, a normal hematocrit and a constant body weight.

For studies requiring blood samples from the pancreatic and gastric veins, another group of 12 healthy mongrel dogs (body wt 27-33 kg) were subjected to laparotomy under Nembutal anesthesia. A silastic catheter was placed, as previously described (6), in the pancreaticoduodenal vein, in a major short gastric vein draining the furdus of the stomach, in the left gastroepiploic vein draining the antrum, and in the inferior vena cava. After placement of the catheters, an equilibration period of $1 \mathrm{~h}$ preceded each experiment.

Pork glucagon (Novo Research Laboratories, Copenhagen, Denmark) and crystalline insulin (Eli Lilly \& Co., Indianapolis, IN) diluted in $0.9 \%$ saline containing $0.3 \%$ bovine serum albumin was used in these studies and administered via a crural vein using a Harvard peristaltic pump (Harvard Apparatus Co., Inc., S. Natick, MA).

Plasma somatostatin-like immunoreactivity $(\mathrm{SLI})^{1}$ was

${ }^{1}$ Abbreviations used in this paper: IRG, immunoreactive glucagon; IRI, immunoreactive insulin; SLI, somatostatinlike immunoreactivity. 
measured by the previously reported modification (7) of the radioimmunoassay of Arimura et al. (8) and Kronheim et al. (9) using antiserum $80 \mathrm{C}$ raised in this laboratory. This assay has been validated for measurements in unextracted canine plasma (7). Plasma insulin (IRI) and glucagon (IRG) levels were determined as previously described $(10,11)$ and glucose concentrations were measured by the glucose oxidase method using the Technicon Autoanalyzer (Technicon Instrument Co., San Francisco, CA). Acute change in plasma SLI has previously been shown to be entirely the result of change in 1,600 D SLI (12).

For statistical analysis, the data was treated by analysis of variance and by the Newman-Keuls procedure for multiple comparisons. A level $<0.05$ was considered significant.

\section{RESULTS}

Effect of glucagon infusion on plasma SLI in normal conscious dogs. Glucagon was infused intravenously into six normal conscious dogs at a rate of 6 , 36 , and $120 \mathrm{ng} / \mathrm{kg}$ per min. Plasma glucagon concentration rose from a mean base-line value of $72.1 \pm 1.1$ $\mathrm{pg} / \mathrm{ml}$ to the supraphysiologic levels of $391 \pm 14$, $1,609 \pm 37$, and $5,777 \pm 280 \mathrm{pg} / \mathrm{ml}$, respectively. Al-

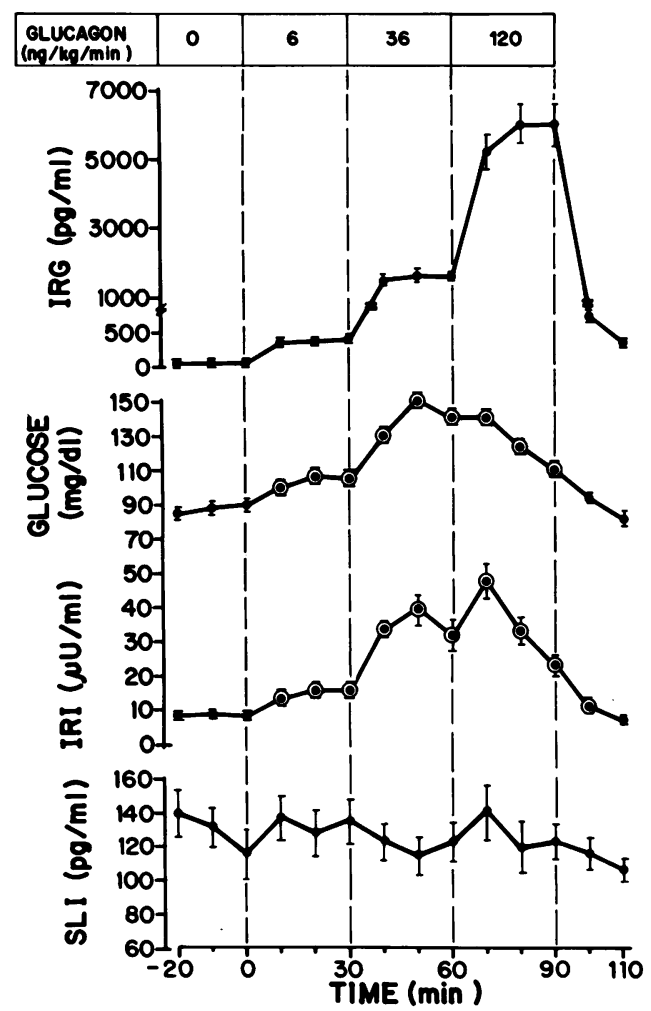

Figure 1 Mean ( \pm SEM) plasma levels of IRG, glucose, IRI, and SLI during the intravenous infusion of glucagon at various rates in six normal, conscious dogs. Encircled points signify a statistically significant difference from mean of the base-line value $(P<0.05)$. though both plasma glucose and IRI levels rose significantly, the SLI level did not change (Fig. 1).

Effect of glucagon infusion on plasma SLI in alloxan diabetic dogs. Because the glucagon-induced rise in insulin, which has been reported to inhibit somatostatin secretion $(3,4,13)$, might have inhibited a $D$ cell response, glucagon was infused at a rate of 6,36 , and $120 \mathrm{ng} / \mathrm{kg}$ in a group of insulin-deprived alloxan diabetic dogs, whose pancreases were subsequently shown to be incapable of increased insulin secretion. Plasma glucagon levels rose from the mean base-line value of $128 \pm 3$ to $405 \pm 4 \mathrm{pg} / \mathrm{ml}$ during infusion of $6 \mathrm{ng} / \mathrm{kg}$ per min, $1,412 \pm 51 \mathrm{pg} / \mathrm{ml}$ during infusion of $36 \mathrm{ng} / \mathrm{kg}$ per min and 5,924 $\pm 229 \mathrm{pg} / \mathrm{ml}$ during infusion of $120 \mathrm{ng} / \mathrm{kg}$ per min (Fig. 2). Plasma glucose level also increased significantly $20 \mathrm{~min}$ after the start of the glucagon infusion $(6 \mathrm{ng} / \mathrm{kg}$ per $\mathrm{min}$ ) and rose gradually to a peak value of $303 \pm 17 \mathrm{mg} / \mathrm{dl}$ at $30 \mathrm{~min}$ after the start of glucagon infusion.

Plasma SLI did not change during glucagon infusion at 6 or $36 \mathrm{ng} / \mathrm{kg}$ per min but rose significantly during the $120 \mathrm{ng} / \mathrm{kg}$ per min infusion from the mean baseline value of $170 \pm 9 \mathrm{pg} / \mathrm{ml}$ to a peak value of $279 \pm 38$ $\mathrm{pg} / \mathrm{ml}$ at $30 \mathrm{~min}$ after the start of the glucagon infusion $(P<0.05)$. SLI levels fell promptly upon cessation of the glucagon infusion (Fig. 2).

Effect of insulin on the glucagon-induced rise of plasma SLI levels in alloxan diabetic dogs. To de-

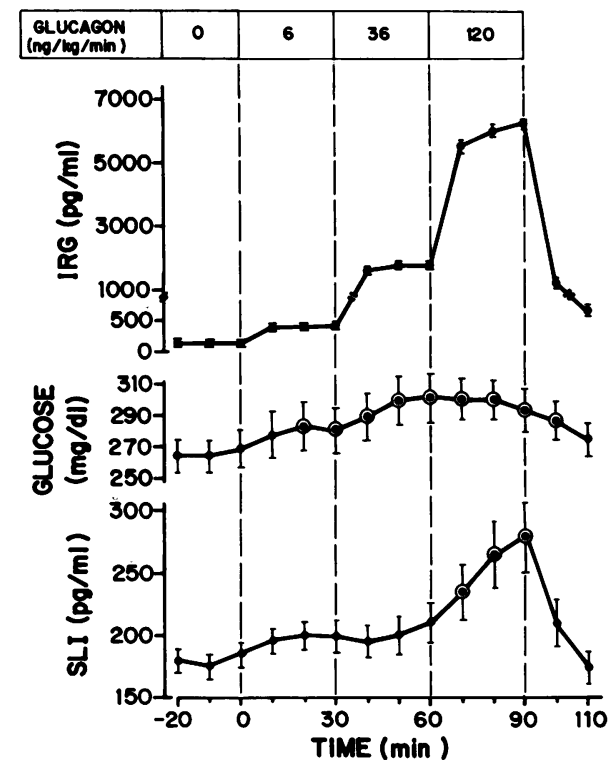

Figure 2 Mean ( \pm SEM) plasma concentrations of IRG, glucose, and SLI during the intravenous infusion of glucagon at a varying rate in 10 conscious, alloxan diabetic dogs. Encircled points signify a statistically significant difference from the mean of the base-line value $(P<0.05)$. 
termine if the response of SLI to the high rate glucagon infusion in the diabetic dogs could be prevented by insulin, the foregoing experiments were repeated in the same dogs but insulin was coinfused with the same amounts of glucagon in concentrations designed to maintain the insulin-glucagon molar ratio in the infusate near the physiologic base-line level of $\sim 2.9$. The insulin-glucagon ratios calculated in plasma from the inferior vena cava during each rate of infusion ranged from 2.3 to 3.8 . Although the increase in plasma glucagon level was similar to that observed in the absence of insulin, the glucagon-induced rise in plasma glucose was prevented. It is unlikely that glucose, rather than glucagon, caused the rise in SLI since glucose has a negligible effect on SLI (14), while glucagon is a powerful stimulus of somatostatin (1).

Under these circumstances, the increase in plasma SLI observed during the infusion of glucagon alone did not occur (Fig. 3).

Effect of glucagon infusion on plasma SLI levels in pancreatic and gastric veins of normal dogs. To determine if, despite the absence of a glucagon-induced rise in peripheral plasma SLI levels in normal dogs, SLI increases in the venous effluent of the pancreas and stomach, glucagon was infused at a rate of 4,24 , and $80 \mathrm{ng} / \mathrm{kg}$ per $\mathrm{min}$ in anesthetized nondiabetic dogs with sampling catheters in the appropriate splanchnic veins. The mean peripheral venous plasma

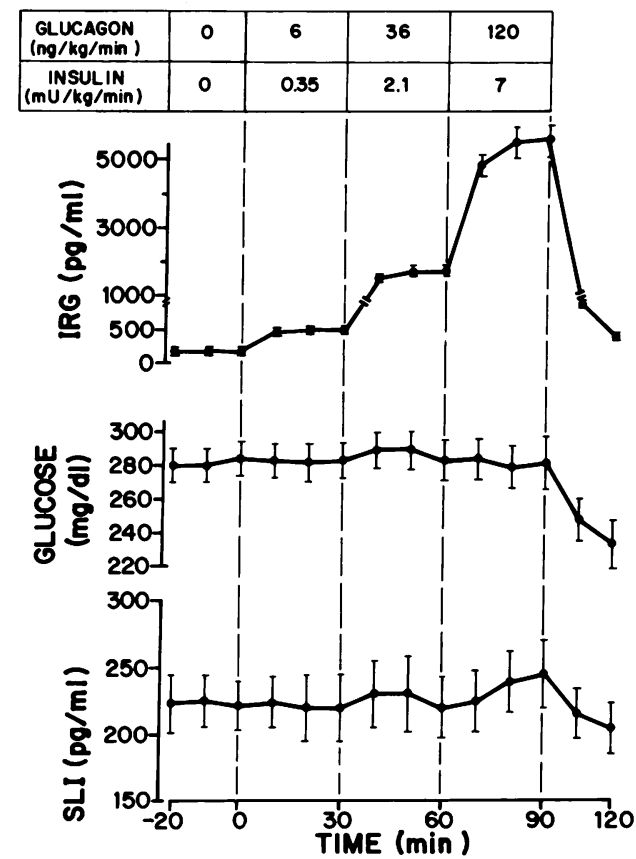

Figure 3 Mean ( \pm SEM) plasma IRG, glucose, and SLI levels during the intravenous infusion of glucagon and insulin in nine conscious, alloxan diabetic dogs.
IRG levels during the infusion rose from a base-line value of $115 \pm 1$ to $395 \pm 19 \mathrm{pg} / \mathrm{ml}$ during the $4-\mathrm{ng} / \mathrm{kg}$ per min glucagon infusion, to $1,947 \pm 45 \mathrm{pg} / \mathrm{ml}$ during the $24-\mathrm{ng} / \mathrm{kg}$ per min infusion, and to $6,358 \pm 207 \mathrm{pg} /$ $\mathrm{ml}$ during the $80-\mathrm{ng} / \mathrm{kg}$ per min infusion. The changes in plasma glucose were similar to those noted in conscious dogs. The mean base-line plasma IRI value of anesthetized dogs was significantly higher than that of conscious dogs $(18.6 \pm 2.4$ vs. $8.5 \pm 1.9 \mu \mathrm{U} / \mathrm{ml}, P$ $<0.001$ ) and rose during the glucagon infusion in a somewhat more gradual pattern than in the conscious animals. Peripheral venous SLI levels once again did not change significantly during the glucagon infusion.

As shown in Fig. 4, SLI levels in the pancreatic effluent plasma rose significantly within $20 \mathrm{~min}$ after the start of the 4-ng/ $\mathrm{kg}$ per min glucagon infusion from a base-line value of $275 \pm 29$ to $397 \pm 59 \mathrm{pg} / \mathrm{ml}$ ( $P$ $<0.05$ ) and reached a peak value of $539 \pm 99 \mathrm{pg} / \mathrm{ml}$ $10 \mathrm{~min}$ after the start of $80 \mathrm{ng} / \mathrm{kg}$ per min of glucagon infusion. Within $20 \mathrm{~min}$ after the end of infusion SLI level had returned to the base-line level. Also, SLI levels in the fundic vein increased significantly within 10 min after the start of the 4-ng/ $\mathrm{kg}$ per min infusion and reached a peak value at $10 \mathrm{~min}$ after the start of the $80-\mathrm{ng} / \mathrm{kg}$ per min infusion. In the venous effluent of the antrum, SLI first increased with the $24-\mathrm{ng} / \mathrm{kg}$ per min infusion rate and reached a peak value at 10 min after the start of $80 \mathrm{ng} / \mathrm{kg}$ per min of glucagon infusion.

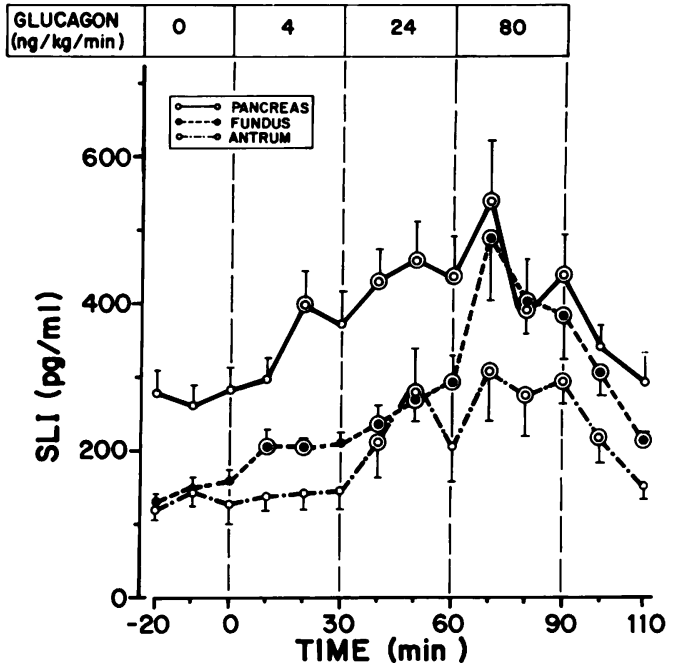

Figure 4 Mean ( \pm SEM) plasma SLI levels in the pancreaticoduodenal, short gastric (fundic), and gastroepiploic (antral) veins during the intravenous infusion of glucagon at varying rates in six normal, anesthetized dogs. Encircled points signify a statistically significant difference from the mean of the base-line values $(P<0.05)$ 
Effect of insulin on the glucagon-induced increase in plasma SLI levels in pancreatic and gastric veins. To determine if insulin increments proportional to the glucagon increments would prevent the glucagonstimulated increase in plasma SLI level in the pancreatic and gastric veins, insulin was coinfused with glucagon in anesthetized normal dogs to maintain a constant insulin-glucagon ratio in a physiologic range. IRG rose as in the absence of insulin and insulin rose in a relatively parallel fashion (Fig. 5). Glucose levels nevertheless rose significantly to a peak of $130 \mathrm{mg} / \mathrm{dl}$.

Under these circumstances a significant rise in plasma SLI concentration in the pancreaticoduodenal and gastroepiploic veins during the 4- and $24-\mathrm{ng} / \mathrm{kg}$ per min infusions did not occur (Fig. 6). At the highest glucagon infusion rate $(80 \mathrm{ng} / \mathrm{kg}$ per min) a significant rise in SLI occurred in both the pancreatic and antral effluent, but the magnitude of this increase was less than during the infusion of glucagon alone (Fig. 5). In the fundic vein, however, a significant increase was observed at one point during the $24-\mathrm{ng} / \mathrm{kg}$ per min infusion and the SLI rise during the $80-\mathrm{ng} / \mathrm{kg}$ per min infusion appeared to be even greater than in the absence of insulin.

\section{DISCUSSION}

The present study demonstrates that glucagon in physiologic and supraphysiologic concentrations stimulates splanchnic SLI release in both normal dogs and alloxan diabetic dogs. However, this is not reflected by a change in the peripheral venous SLI levels of normal dogs even when the levels of exogenous glucagon $>5,000 \mathrm{pg} / \mathrm{ml}$. In diabetic dogs, however, peripheral vein SLI rise significantly when glucagon levels are increased above $5,000 \mathrm{pg} / \mathrm{ml}$, a value that is occasionally attained in severe diabetic ketoacidosis, renal failure, and shock

Despite the lack of a rise in peripheral venous SLI release in nondiabetic dogs at even the highest infusion rate, SLI release from both pancreas and the gastric fundus was enhanced by even the lowest rate glucagon infusion, which raised glucagon levels to $395 \mathrm{pg} / \mathrm{ml}$, slightly above the physiologic range. $(90 \mathrm{pg} / \mathrm{ml}$ is the lowest concentration of exogenous glucagon that causes a significant increase in SLI release from isolated, perfused normal dog pancreases [5].) Thus, it is most unlikely that physiologic changes in glucagon can influence the peripheral venous level of SLI, but they might be capable of enhancing pancreatic and gastric somatostatin secretion which might, therefore, exert local actions. Also, locally high concentrations of glucagon could influence adjacent $D$ cells via paracrine action.

The administration of insulin with the glucagon at a rate that kept the insulin-glucagon molar ratio within

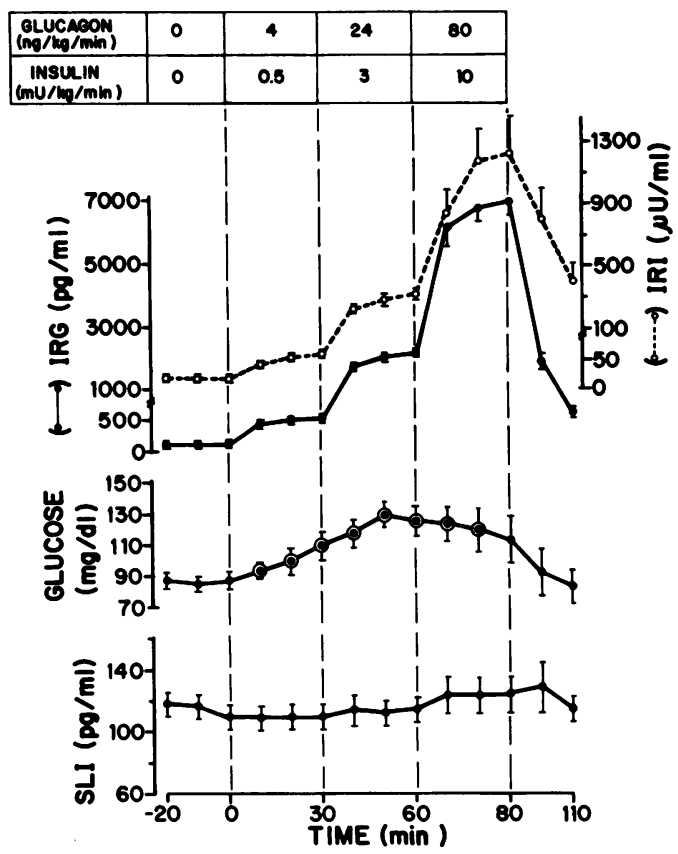

Figure 5 Mean ( \pm SEM) plasma IRG, glucose, and SLI levels during intravenous glucagon and insulin infusion in six normal, anesthetized dogs. Encircled points signify a statistically significant difference from the mean of the base-line values $(P<0.05)$.

a physiologic range abolished or inhibited glucagonmediated stimulation of pancreatic and antral (but not fundic) SLI secretion in the normal anesthetized dogs and abolished the rise in peripheral vein SLI levels in conscious diabetic dogs. Thus, the pancreatic and antral D cell, like the hepatocyte and the adipocyte, appears to be influenced in opposite biologic directions by the

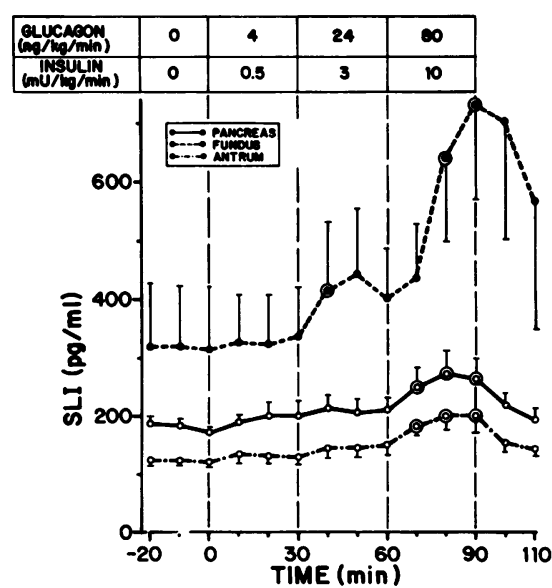

Figure 6 Mean ( \pm SEM) plasma SLI levels in pancreaticoduodenal, short gastric (fundic), and gastroepiploic (antral) veins during the intravenous administration of glucagon and insulin in six normal, anesthetized dogs. 
two hormones, and its function may be, at least in part, controlled by the relative concentration of each hormone. In the normal islet the concentration of insulin that perfuses D cells is probably extremely high, at least in the rat (15); in that species the islet blood probably passes first through the $B$ cell-rich medulla and last through the glucagon- and somatostatin-rich cortex. By contrast, much of the glucagon entering the circulating probably reaches adjacent $D$ cells by recirculating (5). If this is true in the dog, the $D$ cells would normally be exposed to a very high insulin-glucagon ratio, which should restrain somatostatin secretion. This high insulin-low glucagon environment would be lacking in the insulinopenic diabetic in whom circulating glucagon levels are high (16) and insulin secretion is virtually absent. This difference may account for the hypersomatostatinemia previously reported in untreated alloxan diabetic dogs and its correction by insulin infusion (15). In the present studies the base-line SLI values of normal conscious dogs averaged $139 \pm 8 \mathrm{pg} / \mathrm{ml}$ and that of conscious diabetic dogs $201 \pm 12 \mathrm{pg} / \mathrm{ml}(P<0.01)$. Thus, like certain other diabetic abnormalities (16), diabetic hypersomatostatinemia may result from the lack of insulin in the presence of glucagon.

\section{ACKNOWLEDGMENTS}

The authors wish to thank the following persons for their expert technical assistance: Loretta Clendenen, Helen Gibson, Virginia Harris, Kay McCorkle, Willie McFarland, Lovie Peace, and Daniel Sandlin.

This work was supported by Veterans Administration Institutional Research Support grant 549-8000-01 and National Institutes of Health grant AM-02700-16.

\section{REFERENCES}

1. Patton, G. S., E. Ipp, R. E. Dobbs, L. Orci, W. Vale, and R. H. Unger. 1977. Pancreatic immunoreactive somatostatin release. Proc. Natl. Acad. Sci. USA. 74: 21402143.

2. Chiba, T., Y. Seino, Y. Goto, S. Kadowaki, T. Taminato, H. Abe, Y. Kato, S. Matsukura, M. Nozawa, and H. Imura. 1978. Somatostatin release from isolated perfused rat stomach. Biochem. Biophys. Res. Commun. 75: 731737.

3. Schauder, P., C. McIntosh, U. Panten, J. Arends, R. Arnold, H. Frerichs, and W. Creutzfeldt. 1978. Dynamics of somatostatin and insulin release from isolated rat pancreatic islets: evidence for intra-islet interactions between B-cells and D-cells. Metab. Clin. Exp. 27(Suppl. 1): 1211-1214.
4. Gerber, P. P. G., E. R. Trimble, C. B. Wollheim, and A. E. Renold. 1981. Effect of insulin on glucose and arginine stimulated somatostatin secretion from the isolated perfused rat pancreas. Endocrinology. 109: 279283.

5. Kawai, K., L. Orci, E. Ipp, A. Perrelet, and R. H. Unger. 1982. Circulating somatostatin acts on the islets of Langerhans via a somatostatin-poor compartment. Science (Wash. DC). 218: 477-478.

6. Schusdziarra, V., V. Harris, J. M. Conlon, A. Arimura, and $R$. H. Unger. 1978. Pancreatic and gastric somatostatin release in response to intragastric and intraduodenal nutrients and $\mathrm{HCl}$ in the dog. J. Clin. Invest. 62: 509-518.

7. Harris, V., J. M. Conlon, C. B. Srikant, K. McCorkle, V. Schusdziarra, E. Ipp, and R. H. Unger. 1978. Measurement of somatostatin-like immunoreactivity in plasma. Clin. Chim. Acta. 87: 275-283.

8. Arimura, A., H. Sato, D. H. Coy, and A. V. Schally. 1975. Radioimmunoassay for GH-release inhibiting hormone. Proc. Soc. Exp. Biol. Med. 148: 784-789.

9. Kronheim, S., M. Berelowitz, and B. L. Pimstone. 1976. A radioimmunoassay for growth hormone release inhibiting hormone. Method and quantitative tissue distribution. Clin. Endocrinol. 5: 619-630.

10. Yalow, R. S., and S. A. Berson. 1960. Immunoassay of endogenous plasma insulin in man. J. Clin. Invest. 39: 1157-1175.

11. Faloona, G. R., and R. H. Unger. 1974. Glucagon. In Methods of Hormone Radioimmunoassay. B. M. Jaffe and H. R. Behrman, editors. Academic Press, Inc., New York. 317-330.

12. Schusdziarra, V., E. Zyznar, D. Rouiller, V. Harris, and R. H. Unger. 1980. Free somatostatin in the circulation: amounts and molecular sizes of somatostatin-like immunoreactivity in portal, aortic and vena caval plasma of fasting and meal-stimulated dogs. Endocrinology. 107: 1572-1576.

13. Rouiller, D., V. Schusdziarra, and R. H. Unger. 1981. Insulin inhibits somatostatin-like immunoreactivity release stimulated by intragastric $\mathrm{HCl}$. Diabetes. 30: 735738.

14. Schusdziarra, V., D. Rouiller, V. Harris, J. M. Conlon, and $R$. H. Unger. 1978. The response of plasma somatostatin-like immunoreactivity to nutrients in normal and alloxan diabetic dogs. Endocrinology. 103: 22642273.

15. Bonner-Weir, S., and L. Orci. 1982. New perspectives on the microvasculature of the islets of Langerhans in the rat. Diabetes. In press.

16. Unger, R. H., E. Aguilar-Parada, W. A. Müller, and A. M. Eisentraut. 1970. Studies of pancreatic alpha cell function in normal and diabetic subjects. J. Clin. Invest. 49: $837-848$.

17. Unger, R. H., and L. Orci. 1981. Glucagon and the Acell. Physiology and pathophysiology. N. Engl. J. Med. 304: 1518-1524, 1575-1580. 